\title{
"The financial soundness of the Palestinian banking sector: an empirical analysis using the CAMEL system"
}

\begin{tabular}{|c|c|}
\hline AUTHORS & Mohammed T. Abusharbeh (D) https://orcid.org/0000-0002-7978-4359 \\
\hline ARTICLE INFO & $\begin{array}{l}\text { Mohammed T. Abusharbeh (2020). The financial soundness of the Palestinian } \\
\text { banking sector: an empirical analysis using the CAMEL system. Banks and Bank } \\
\text { Systems, 15(1), 85-97. doi:10.21511/bbs.15(1).2020.09 }\end{array}$ \\
\hline DOI & http://dx.doi.org/10.21511/bbs.15(1).2020.09 \\
\hline RELEASED ON & Thursday, 19 March 2020 \\
\hline RECEIVED ON & Thursday, 07 November 2019 \\
\hline \multirow[t]{2}{*}{ ACCEPTED ON } & Monday, 02 March 2020 \\
\hline & 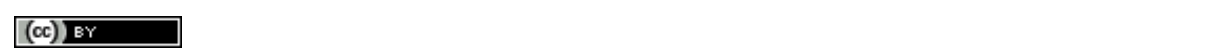 \\
\hline LICENSE & $\begin{array}{l}\text { This work is licensed under a Creative Commons Attribution } 4.0 \text { International } \\
\text { License }\end{array}$ \\
\hline JOURNAL & "Banks and Bank Systems" \\
\hline ISSN PRINT & $1816-7403$ \\
\hline ISSN ONLINE & $1991-7074$ \\
\hline PUBLISHER & LLC "Consulting Publishing Company "Business Perspectives" \\
\hline FOUNDER & LLC "Consulting Publishing Company "Business Perspectives" \\
\hline
\end{tabular}

NUMBER OF REFERENCES

33

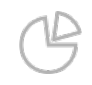

NUMBER OF FIGURES

5

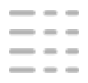

NUMBER OF TABLES

11

(C) The author(s) 2022. This publication is an open access article. 


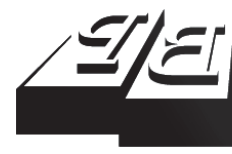

BUSINESS PERSPECTIVES

(O)

LLC "CPC "Business Perspectives"

Hryhorii Skovoroda lane, 10, Sumy, 40022, Ukraine

www.businessperspectives.org
Received on: $7^{\text {th }}$ of November, 2019 Accepted on: 2nd of March, 2020 Published on: $19^{\text {th }}$ of March, 2020

๑ Mohammed T. Abusharbeh, 2020

Mohammed T. Abusharbeh, Doctor, Faculty of Administrative and Financial Sciences, Department of Finance, Arab American University, Country West Bank, Palestine.

\section{THE FINANCIAL SOUNDNESS OF THE PALESTINIAN BANKING SECTOR: AN EMPIRICAL ANALYSIS USING THE CAMEL SYSTEM}

\begin{abstract}
The purpose of this article is to evaluate the financial soundness of commercial banks listed on the Palestine Exchange using the CAMEL rating system. A content analysis, composite rating, and a one sample t-test are applied to a sample of six local banks operating in Palestine. Secondary data were obtained from the financial statements of the banks for the period of 2007-2017 in order to conduct the research and evaluate their financial performance. The empirical test has shown that Palestinian banks adhere to the Basel Committee standards in terms of capital adequacy and that they display stability in terms of profitability and liquidity. However, the paper concludes that the operational efficiency of the banks being evaluated is "fairly managed". Finally, the findings indicate significant differences amongst Palestinian banks in terms of performance, assessed using the CAMEL rating system. This paper suggests that the listed Palestinian banks should focus on long-term investments rather than short-term ones, and monitor their risk management practices to increase their profits and move towards sustainability and growth.
\end{abstract}

\section{Keywords \\ capital adequacy, asset quality, nonperforming loans, performance}

JEL Classification

G21, G24, G28

\section{INTRODUCTION}

The banking sector is one of the main building blocks in the development of the international economy and in particular the Palestinian national economy. It is also considered the main source of funds for businesses and is crucial for facilitating economic growth. In this context, Allay (2013) argued that the banking system plays a leading role in sustaining financial markets and institutions. Hawaldar, Lokesha, Kumar, Pinto, and Sison (2017) stated that the banking sector had a substantial impact on financial inclusion in the national economy. Besides, Abusharbeh (2017) confirmed that the banking sector is considered the main internal source of the Palestinian economy and, thus, improves the productive capacity of the national economy. Therefore, Palestinian commercial banks are taking advanced steps to improve the quality of financial services in order to offer a variety of banking services everywhere in Palestine and to gain a competitive advantage at the local level.

The performance of the banking sector is assessed using the Uniform Financial Institution Rating system (UFIRS) developed in 1997, which is based on a supervisory banking system called CAMEL. In 1988, the Basel Committee proposed this framework as a supervision rating system. This model is categorized as the following ratios: Capital Adequacy, Asset Quality, Operational Efficiency, Earnings, and Liquidity. 
Consequently, the Palestinian Monetary Authority (PMA) evaluated financial soundness of banks based on the International Monetary Fund methodology. It assessed bank performance using four main aspects: capital indicators, asset quality indicators, revenue ratios, and liquidity position (PMA, 2018).

In publishing their annual reports, listed commercial banks fully disclose matters focusing on their financial activities in order to assist agents and investors in their financial decisions and investments. The primary goal of a chief executive officer is to maximize the investors' wealth, which is determined by financial decisions made by bank directors. Therefore, various technical methods are used to assess the performance of banks. Most recent studies have attempted to assess bank performance using the CAMEL model (for example, Kumari, 2017; Ishaq, Karim, Zaheer, \& Ahmed, 2016; Kumar \& Sayani, 2015; and Gupta, 2014). Other studies used the Du Pont model to explain the variation of bank profitability (i.e., Najjar, 2013; Kyriazopoulos, Papaioannou, \& Chrissochoidou, 2013; and Doorasamy, 2016). Indeed, financial ratios are used to establish the association among variables and how they can affect each other. Different business valuation models guide the firms in terms of performance. Nevertheless, many prior literatures confirmed that the CAMEL rating system is appropriate for bank assessment (Raiyani, 2010). In this manner, Roman and Şargu (2013) argued that CAMEL is recommended to measure the financial soundness of the banking sector. It is also classified as an international supervisory rating system. Furthermore, Mekonnen, Kedir, and Shibru (2015) mentioned that this framework was adopted by the Federal Financial Institutions Examination Council in 1979 to assess the overall financial soundness of a bank. Thus, this paper argues that the CAMEL framework could be useful in assessing the financial performance of Palestinian commercial banks. Indeed, the ultimate purpose of this study is to assess bank performance and to examine whether there are any significant differences among Palestinian commercial banks in terms of performance, assessed by CAMEL.

The results of this paper are expected to validate the use of CAMEL in the Palestinian banking sector. Moreover, the results provide an empirical ranking method for Palestinian commercial banks to manage the weaknesses and threats that may prevent these banks from growing.

The remainder of this paper is arranged as follows: Section 1 contains an extensive review of the relevant literature, which assesses bank performance based on CAMEL. Section 2 describes the data and sample selection and explains the CAMEL composite rating criteria, while Section 3 gives results. The last section concludes the empirical results and provides suggestions.

\section{LITERATURE REVIEW AND RESEARCH HYPOTHESES}

Many researchers and academics have evaluated bank performance using the CAMEL system in different ways and over different periods. To fill the gaps of the current paper, this section describes the main components of CAMEL and explores some important empirical works aimed at evaluating the financial soundness of banks.

\subsection{The CAMEL model development}

This ratio-based model was developed in early 1979 and adopted by the Federal Financial Institutions Examination Council in the USA (Barr, Killgo, Siems, \& Zimmel, 2002). It is considered an effec- tive internal control instrument for assessing the soundness of financial institutions. The revisions of UFIRS consist of six significant factors: capital requirements, asset quality, management efficiency, the level of earnings, adequacy of liquidity, and sensitivity to market risk, to ensure that all banks are evaluated in a comprehensive and uniform manner (Dang, 2011). These parameters are used to measure the effectiveness and efficiency of banking systems all over the world (Hirtle \& Lopez, 1999).

Under this model, the evaluation takes into consideration the sophistication of the bank's activities and its risk profile. The CAMEL rating system incorporates five financial ratios to determine the bank's financial performance, focusing on bank 
records from a managerial and financial perspective to identify the weak points and evaluate risk exposure. Rostami (2015) argued that CAMEL was an effective and accurate instrument for evaluating the financial performance of banks, as it could assist managers in identifying the causes of financial problems in the bank. In addition, Soni (2012) stated that this model could be useful for bank accountability and sustainability.

As already noted in the study, the financial analysis of bank performance is based on specific financial ratios that are used in the context of the CAMEL framework. According to this system, the banking sector is rated using five key parameters, including: capital standards, asset utilization, operational efficiency, earnings, and adequacy of liquidity. Moreover, each of the five CAMEL components is rated on a scale of one to five, from a strong financial position to a weak one. These parameters are defined and described as follows.

\subsubsection{Capital adequacy}

Ebhodaghe (1991) defined capital adequacy (CAR) as the situation in which the adjusted capital is able to absorb unexpected losses. It also indicates the bank's ability to maintain the statutory capital requirements in order to grip loss probability. Therefore, an adequate level of capital induces the bank manager to achieve the minimum level of capitalization. Chen (2003) argues that CAR plays a critical role in preventing the bank from going bankrupt and in increasing the depositor's confidence. To calculate CAR, capital should be classified into Tier 1 and Tier 2 . The former includes owners' equity and reserves, while the latter comprises bank subordinated debts (Basel Accords I and II).

\subsubsection{Asset quality}

Asset quality reflects the financial health of the bank against the potential loss value of its assets. Sundararajan et al. (2002) defined it as the capacity of the bank to spread risks and recover default loans. It also measures the sufficiency of loan provisions and the percentage of nonperforming loans from bank assets (Dang, 2011). Basel II stated that asset quality should comprise important factors such as the volume of bank transactions and loan provisions, in addition to the comparison between nonaccrual and nonperforming loans. Therefore, the high utilization of loans and advances leads to a higher probability of credit risks in assets.

\subsubsection{Management efficiency}

According to Basel II, management efficiency reflects the ability of a company to respond to organizational circumstances that may occasionally arise. It also evaluates management competency, leadership, human resources, and corporate governance compliance with banking regulations. Similarly, Aspal and Misra (2013) mentioned that management efficiency lies in its ability to identify, monitor, and control risks associated with the bank, and to devise strategic plans based on the bank's risk perception. However, the characteristics of management are rather qualitative in nature. Therefore, it is hard to draw any conclusions regarding management capability. Nevertheless, Sarker (2006) used some indicators (such as the operating income to operating expense ratio, operating expenses per employee, and the credits and advances to deposits ratio) to evaluate management efficiency. Thus, it is considered a vital CAMEL parameter for improving the quality of a bank and efficient management practices. In fact, this measurement can control bank operating expenses and convert bank deposits into high earning loans and advances. Moreover, management soundness is considered a qualitative measure of the bank's management system. This paper argues that management capabilities can be measured using certain ratios of off-set bank evaluation, such as the credits and the advance-to-deposit and operating expenses-to-operating income ratios.

\subsubsection{Earning capacity}

Basel II views strong earnings as financial strength. It basically measures the profitability of the bank and describes the sustainability and growth of future earnings. It also reflects the capability of the bank to generate income from its total assets (Dang, 2011). Commonly, most previous studies use return on assets as the profitability index. This ratio indicates the extent to which the earnings after tax for each dollar are invested in the assets of the bank. 


\subsubsection{Liquidity position}

This is the ability of banks to fulfill short-term obligations and occasional withdrawals by depositors (Correia et al., 2013). An adequate level of liquidity means that the bank has excess cash to cover its short-term obligations. Therefore, this paper uses liquid assets (cash on hand and cash on other financial institutions) as the percentage of assets to determine the liquidity position of the bank.

\subsection{Relevant empirical works}

In Shanghai, Liu and Pariyaprasert (2014) used the CAMEL model in thirteen listed banks over the period of 2008 to 2011 to determine bank performance. They used capital adequacy, nonperforming financing, interest margin, and loan-to-deposit ratios as indicators of each bank's performance. They found that their performance was significantly influenced by CAR, nonperforming financing, interest margin, and loans to deposits ratios.

In the Gulf, Kumar and Sayani (2015) evaluated the financial soundness of Islamic banks across five regions for the 2008 to 2014 period (Saudi Arabia, United Arab Emirates, Qatar, Bahrain, and Kuwait) using the CAMEL approach. The results indicated that all eleven Islamic banks had adequate capital. It was also found that the banks' profitability and asset quality deteriorated over the period in which the study was conducted.

In Sri Lanka, Kumari (2017) analyzed the performance of foreign commercial banks by applying the CAMEL approach from 2008 to 2014, using capital adequacy, nonperforming loans, return on assets, and loan-to-deposit ratios as parameters. The study found that indicators of the foreign banking sector in terms of capital adequacy and return on assets were more efficient than other indicators.

In Bangladesh, Rahman and Islam (2018) evaluated the performance of conventional banks using the CAMEL model from 2010 to 2016. They found that the Eastern Bank took the lead among the selected banks. Additionally, the paper found that all commercial banks achieved high capital adequacy ratios - over the standard of $10 \%$. The selected banks also had a higher percentage of non-performing loans (NPLs). Therefore, the Central Bank of Bangladesh should strive to overcome the potential losses that result from higher NPLs.

In Jordan, Mousa (2016) measured the performance of Islamic banks based on the CAMEL model from 2010 to 2015. The study found that all Islamic banks maintained the minimum level of capital adequacy. It also concluded that all Islamic banks ranked high in terms of asset quality and earnings.

In Palestine, Kullab and Yan (2018) evaluated the financial soundness of Palestinian banks based on the CAMEL framework from 2008 to 2017, using the OLS regression method to analyze the data. The study found that Palestinian banks maintained the minimum capital adequacy requirements and showed an increase in interest expenses, stability in profitability, and a decline in liquidity position.

In South Africa, Desta (2016) explored the financial performance of African banks using the CAMEL system from 2012 to 2014. This study found that all selected banks were highly rated in terms of capital adequacy and profitability. On the other hand, asset quality and management efficiency were rated as less satisfactory and inefficient, respectively. This paper finally concluded that all banks performed fairly.

In India, Gupta (2014) assessed the financial soundness of Indian banks using the CAMEL system from 2009 to 2013. The results indicated that Indian public banks underperformed and needed to enhance their performances in order to meet minimum standards.

\subsection{Research hypotheses development}

This paper evaluates and compares the performance of Palestinian commercial banks assessed by the CAMEL model through formulating the following alternative hypotheses:
H01: The financial performance of Palestinian commercial banks assessed by CAMEL shows good results.

H02: There are significant differences in performance among commercial banks assessed by the CAMEL model. 
Table 1. Financial position of listed banks (million USD)

\begin{tabular}{|c|c|c|c|c|c|c|}
\hline No. & Name & Code & Total assets & $\begin{array}{l}\text { Customer } \\
\text { deposits }\end{array}$ & Credit facilities & Net profits \\
\hline 1 & Bank of Palestine & $\mathrm{BOP}$ & $4,884.8$ & $3,788.6$ & $2,518.6$ & 54 \\
\hline 2 & Al Quds Bank & QUDS & 1076 & 856 & 659 & 11.2 \\
\hline 3 & Palestine Investment Bank & $\mathrm{PIBC}$ & 443.3 & 276.8 & 210.6 & 3.9 \\
\hline 4 & The National Bank & TNB & $1,079.4$ & 808.8 & 653.9 & 9.2 \\
\hline 5 & Arab Islamic Bank & $\mathrm{AlB}$ & 1041 & 791 & 561 & 6.4 \\
\hline 6 & Palestinian Islamic Bank & ISBK & 1010 & 809.6 & 619.3 & 14.5 \\
\hline & Total & & $9,629.5$ & $7,330.8$ & $5,222.4$ & 99.2 \\
\hline
\end{tabular}

\section{METHODS}

\subsection{Data collection and sampling}

The researcher has collected data from listed Palestinian commercial banks for the 11-year period (2007-2017). Six local banks were included in the analysis, which was conducted based on the annual audited financial statements officially disclosed to the public. The time series data were extracted from the listed banks' annual reports. Table 1 presents the list of banks in the sample.

Table 1 shows the total market value of assets for all operating listed banks in Palestine - USD 9.6 billion. Meanwhile, the total customer deposits amounted to USD 7.3 billion, while credit facilities came to only USD 5.2 billion. However, an annual profit of USD 99 million was made by the end of 2018 .

\subsection{The CAMEL model (measuring variables)}

The ratio-based CAMEL model is widely used in most recent empirical studies. Therefore, the researcher uses specific financial ratios to define the respective parameters of the CAMEL rating system. The selective ratios are commonly used by the Palestinian Monetary Authority (PMA) and demonstrated in prior studies, such as Aspal and Dhawan (2016), and Kumari (2017). Table 2 describes financial ratios that measure each acronym of the CAMEL rating system.

\subsection{Composite rating criteria}

The composite CAMEL rating is ranked from 1 to 5 according to the status of the bank. Thus, bank performance is assessed using a rating scale as

Table 2. Ratio-based model (CAMEL)

\begin{tabular}{l|c|c}
\hline \multicolumn{1}{c}{ Ratio } & Acronym & Description \\
\hline Capital Adequacy Ratio & $\mathrm{C}$ & Bank capital/Risk weighted assets \\
\hdashline Asset Quality & $\mathrm{A}$ & Nonperforming loans/Loans and Advances \\
Management Efficiency & $\mathrm{M}$ & Operating expenses/Operating income \\
\hline Earnings (ROA) & $\mathrm{E}$ & Measured by net income/Total assets \\
\hdashline Liquidity & $\mathrm{L}$ & (Cash on hand and cash in other banks)/Total assets \\
\hline
\end{tabular}

Table 3. Composite rating based on CAMEL

\begin{tabular}{c|c|c|c}
\hline Rating & Composite range & Status & Description \\
\hline 1 & $1-1.49$ & Strong & The bank's performance is very strong. \\
\hline 2 & $1.5-2.49$ & Superior & The bank's performance is good, but there are some weaknesses. \\
\hdashline 3 & $2.5-3.49$ & Fair & The bank's performance is acceptable with some associated risks. \\
\hdashline 4 & $3.5-4.49$ & Marginal & The bank has many financial weaknesses that could potentially \\
& & & threaten its growth and development. \\
\hline 5 & $4.5-5$ & Unsatisfactory & The bank has a high probability of failure and bankruptcy. \\
\hline
\end{tabular}


Table 4. Classification rating of CAMEL parameters

Source: Author estimation.

\begin{tabular}{|c|c|c|c|c|c|}
\hline \multirow{2}{*}{ Ratios } & \multicolumn{5}{|c|}{ Composite rating } \\
\hline & 1 & 2 & 3 & 4 & 5 \\
\hline Capital Adequacy (CAR) & $>13 \%$ & $12-12.99 \%$ & $8-11.99 \%$ & $6-7.99 \%$ & $<5.99 \%$ \\
\hline Asset Quality (NPLs) & $<1.5$ & $2.5-1.51 \%$ & $3.5-2.6 \%$ & $5.5-3.6 \%$ & $>5.6 \%$ \\
\hline Management Efficiency (OE/OI) & $<60 \%$ & $60-74.9 \%$ & $75-89.9 \%$ & $90-99.9 \%$ & $>100 \%$ \\
\hline Earnings Capability (ROA) & $>1 \%$ & $0.6-0.99 \%$ & $0.5-0.599 \%$ & $0.3-0.499 \%$ & $<0.29 \%$ \\
\hline Liquidity (Liquid asset) & $>50 \%$ & $40-49.9 \%$ & $30 \%-39.9 \%$ & $20 \%-29.9 \%$ & $<19.9 \%$ \\
\hline
\end{tabular}

presented in Table 3. This assessment method was supported by many scholars, such as Sarker (2006), and Desta (2016).

Table 4 details the classifications of the CAMEL rating system. The selected ratios are evaluated using this rating system. A rating of one indicates strong performance, while a rating of five indicates poor performance.

\section{RESULTS}

\subsection{Capital adequacy}

Table 5 represents the descriptive statistics of mean, standard deviation, and the composite rating of capital adequacy ratios for each bank over the past 11 years. The result shows that the lowest mean value of CAR is $15.25 \%$ for BOP, while the highest observed value is $25.88 \%$ for TNB. All banks have reached the minimum capital standards of $10 \%$, as stated by the Basel Committee, and all have received a rating of 1 . On average, Palestinian commercial banks have the ability to yield minimum revenue of $12.2 \%$ (22.2\%-10\%) from their existing capital to further invest in the Palestinian economy. As a result, Palestinian commercial banks are able to maintain the confidence of shareholders and customer depositors and to absorb any potential shocks that might be incurred.

Table 5. Average capital adequacy ratio (2007-2017)

\begin{tabular}{|c|c|c|c|c|}
\hline Bank & Mean & SD & Composite rating & Evaluation \\
\hline $\mathrm{BOP}$ & $15.27 \%$ & $2.79 \%$ & 1 & Good \\
\hline QUDS & $21.62 \%$ & $5.92 \%$ & 1 & Good \\
\hline PIBC & $20.91 \%$ & $3.46 \%$ & 1 & Good \\
\hline TNB & $25.88 \%$ & $13.12 \%$ & 1 & Good \\
\hline $\mathrm{AIB}$ & $17.82 \%$ & $3.23 \%$ & 1 & Good \\
\hline ISBK & $22.69 \%$ & $8.45 \%$ & 1 & Good \\
\hline Industry average & $22.20 \%$ & $6.16 \%$ & 1 & Good \\
\hline
\end{tabular}

\section{Capital adequacy ratio}

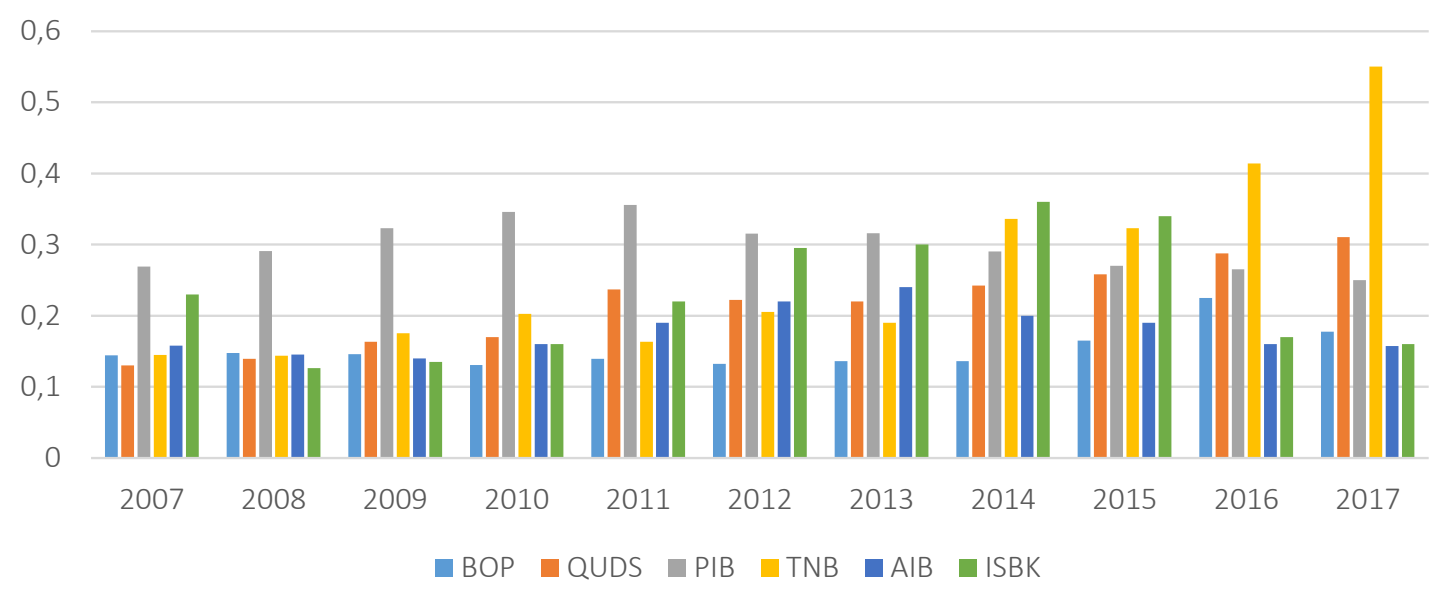

Figure 1. Capital adequacy ratio for the listed banks (2007-2017) 


\subsection{Asset quality}

Table 6 shows the results of nonperforming loans (NPLs) over the research period and specifies the percentages of bank loans that have been written off due to uncollectable fund. The table concludes that AIB has successfully managed its NPLs over the past eleven years. The average NPLs constituted $1.6 \%$ of loan provisions and received a rating of 1 . This implies that AIB has a well-defined credit policy. On the other hand, QUDS has a high credit risk due to a higher percentage of nonperforming loans over the study period. The mean value of NPLs for QUDS was $6.24 \%$ with a deviation of 7\%. However, this indicates that QUDS' bank management relatively attempted to control its credit policy through raising collateral requirements. Similarly, the NPL averages of TNB and PIB were $5.8 \%$ and $4.42 \%$, respectively, both receiving a rating of 4 . Thus, asset quality is measured using NPLs which have been relatively varied over the past 11 years, with an average of $4 \%$ among Palestinian commercial banks. Thus, the asset quality of each bank seems sufficient to control credit risks. Therefore, NPLs are ever-fluctuating due to the Palestinian macro-economy instability and the continuous financing of unqualified projects.

\subsection{Management capabilities}

Table 7 reveals that the average OEOI of BOP was $54.6 \%$, the lowest percentage out of other listed banks, but received a rating of 1 . This indicates that BOP has a higher operational efficiency as compared with other local competitors. Nevertheless, TNB had the highest ratio (118\%), but received a rating of 5. This implies that TNB has failed to manage its operational efficiency compared to other listed banks, which are fairly organized in their management capabilities, considering the potential risks they are exposed to.

Figure 3 demonstrates that in 2008, TNB saw a tremendous increase in operating expenses due to the deterioration of its financial position; this indicates the TNB's inability to control its opera-

Table 6. Average non-performing loans (2007-2017)

\begin{tabular}{|c|c|c|c|c|}
\hline Bank & Mean & SD & Composite rating & Evaluation \\
\hline BOP & $2.51 \%$ & $1.01 \%$ & 2 & Superior \\
\hline QUDS & $6.24 \%$ & $7.05 \%$ & 5 & Unsatisfactory \\
\hline PIBC & $5.80 \%$ & $3.48 \%$ & 4 & Marginal \\
\hline TNB & $4.42 \%$ & $2.92 \%$ & 4 & Marginal \\
\hline AIB & $1.57 \%$ & $0.81 \%$ & 2 & Superior \\
\hline ISBK & $3.91 \%$ & $2.83 \%$ & 3 & Fair \\
\hline Industry average & $4.08 \%$ & $3.02 \%$ & 3.3 & Fair \\
\hline
\end{tabular}

Nonperforming loans

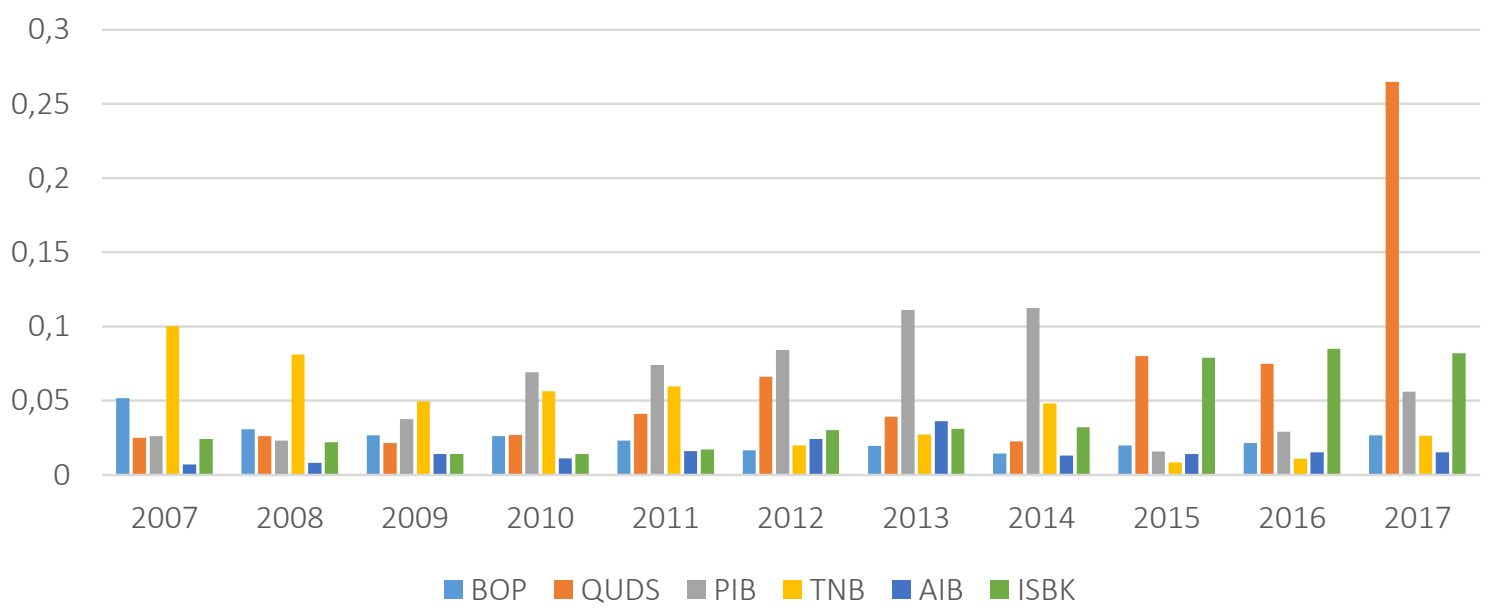

Figure 2. Nonperforming loans of listed banks (2007-2017) 


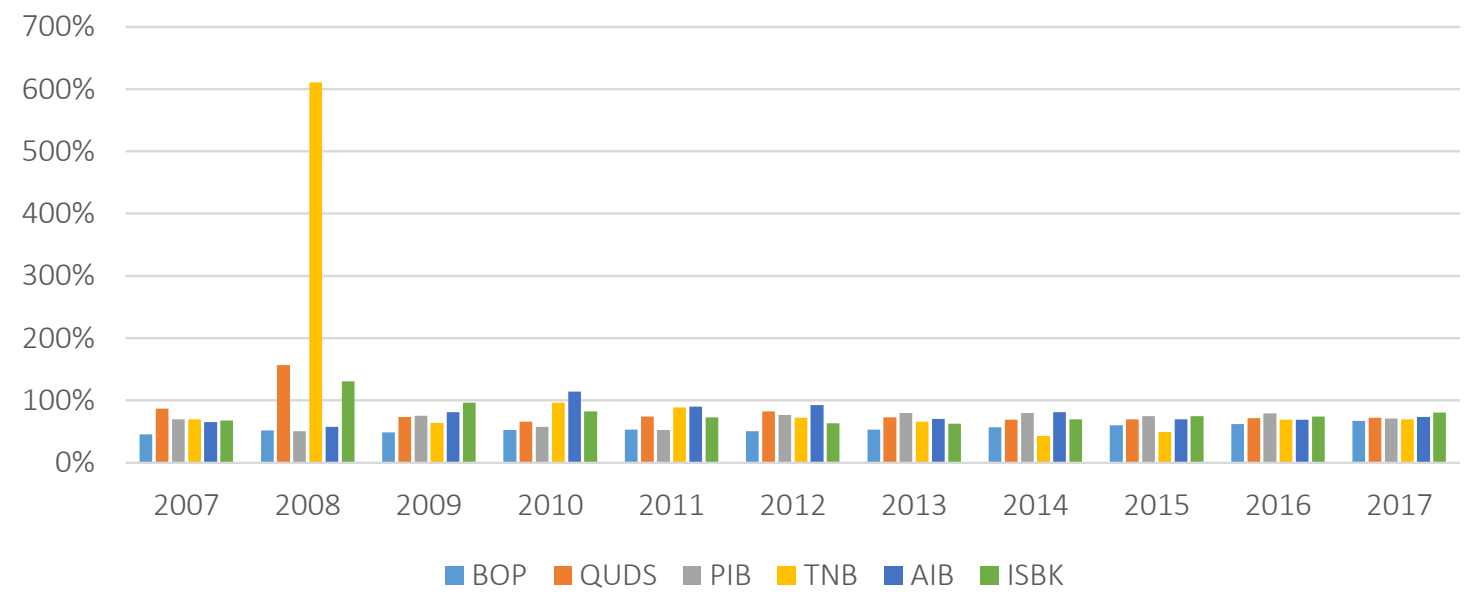

Figure 3. Operational efficiency ratio of listed banks (2007-2017)

Table 7. Operating expenses to operating income (2007-2017)

\begin{tabular}{|c|c|c|c|c|}
\hline Bank & Mean & SD & Composite Rating & Evaluation \\
\hline BOP & $54.61 \%$ & $6.26 \%$ & 1 & Good \\
\hline QUDS & $81.29 \%$ & $25.75 \%$ & 3 & Fair \\
\hline PIBC & $69.74 \%$ & $11.04 \%$ & 2 & Superior \\
\hline TNB & $118 \%$ & $164 \%$ & 5 & Unsatisfactory \\
\hline$A I B$ & $78.61 \%$ & $15.80 \%$ & 3 & Fair \\
\hline ISBK & $73.49 \%$ & $29.21 \%$ & 2 & Superior \\
\hline Industry average & $79.31 \%$ & $42.01 \%$ & 2.67 & Fair \\
\hline
\end{tabular}

tional risks. Despite this, Palestinian commercial banks have achieved fair operational efficiency over the past eleven years.

\subsection{Earnings}

Table 8 shows the efficiency of Palestinian banks in investing their loans and advances. The average ROA ratio ranged between $1.9 \%-0.3 \%$. Moreover, BOP and PIB both showed adequate levels of earnings: $1.88 \%$ and $1.03 \%$, respectively. Both received a rating of 1 . However, TNB had the lowest average of $0.3 \%$ and received a rating of 4 . This implies that these banks follow a conservative lending policy to avoid risks.

\subsection{Adequate liquidity}

Table 9 concludes that liquid asset ratios of all listed commercial banks have slightly fluctuated over the eleven-year study period. This is due to an avoidance in granting funds provided by the banks, which indicates that the listed banks do not utilize their funds, such as credit facilities and long-term investments, efficiently. Despite this downturn, liquid assets still occupy a higher per-

Table 8. Average return on assets (2007-2017)

\begin{tabular}{|c|c|c|c|c|}
\hline Bank & Mean & SD & Composite rating & Evaluation \\
\hline $\mathrm{BOP}$ & $1.88 \%$ & $0.50 \%$ & 1 & Good \\
\hline QUDS & $0.61 \%$ & $0.99 \%$ & 2 & Superior \\
\hline PIBC & $0.95 \%$ & $0.35 \%$ & 2 & Superior \\
\hline TNB & $0.29 \%$ & $1.21 \%$ & 4 & Marginal \\
\hline AIB & $0.90 \%$ & $0.51 \%$ & 2 & Superior \\
\hline ISBK & $1.03 \%$ & $0.86 \%$ & 1 & Good \\
\hline Industry average & $0.94 \%$ & $0.74 \%$ & 2 & Superior \\
\hline
\end{tabular}




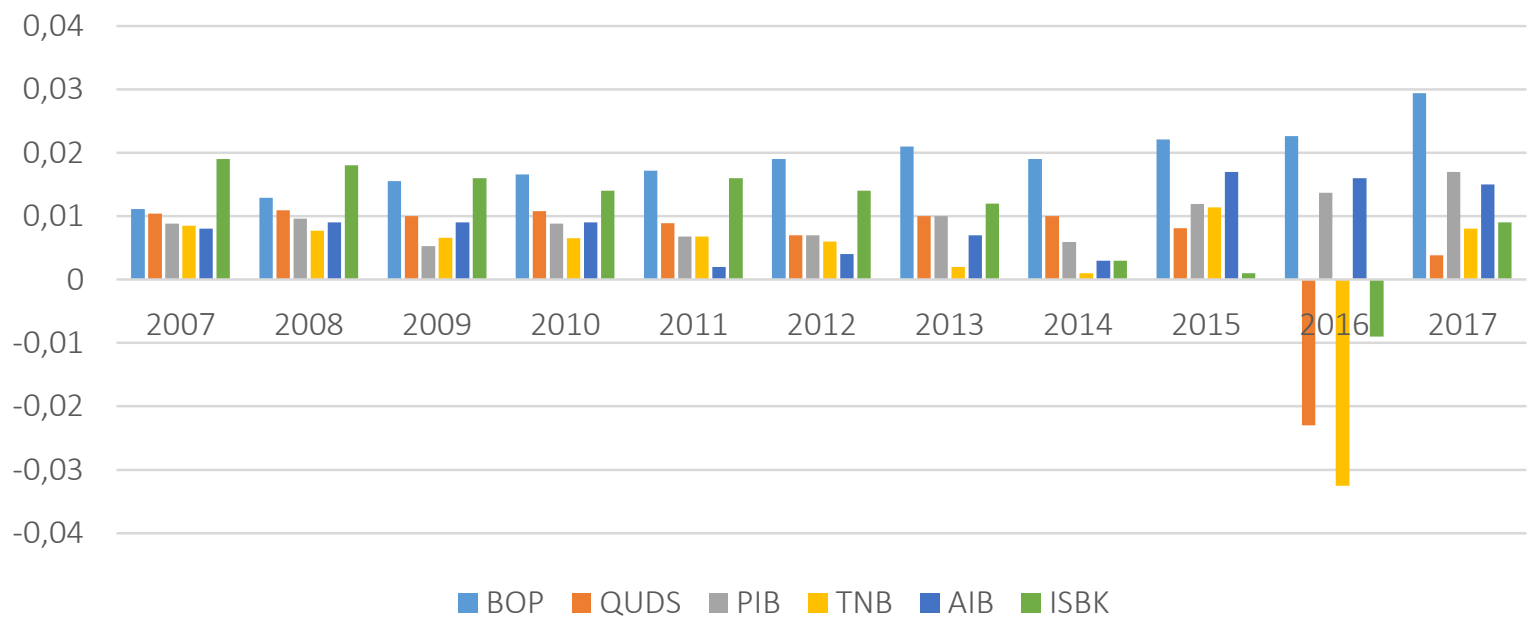

Figure 4. Return on assets of listed banks (2007-2017)

centage than bank assets. The average liquidity ratio is $48 \%$, with a deviation of $12 \%$ and a ranking of 2. Thus, Palestinian commercial banks have the ability to meet their short-term obligations and to develop efficient strategies for increasing liquidity during periods of financial instability.

\subsection{Overall CAMEL assessment}

Table 10 reveals that BOP and ISBK demonstrated strong performance, each receiving a rating of 1 . Meanwhile, AIB was ranked second among other listed commercial banks. PIBC's performance was

Table 9. Average liquid assets (2007-2017)

\begin{tabular}{|c|c|c|c|c|}
\hline Bank & Mean & SD & Composite rating & Evaluation \\
\hline BOP & $44.38 \%$ & $8.28 \%$ & 2 & Superior \\
\hline QUDS & $38.38 \%$ & $14.91 \%$ & 3 & Fair \\
\hline PIBC & $49.98 \%$ & $10.55 \%$ & 2 & Superior \\
\hline TNB & $47.09 \%$ & $12.01 \%$ & 2 & Superior \\
\hline$A I B$ & $56.75 \%$ & $10.72 \%$ & 1 & Good \\
\hline ISBK & $51.14 \%$ & $16.09 \%$ & 1 & Good \\
\hline Industry average & $47.95 \%$ & $12.09 \%$ & 1.83 & Superior \\
\hline
\end{tabular}

Liquid assets ratio

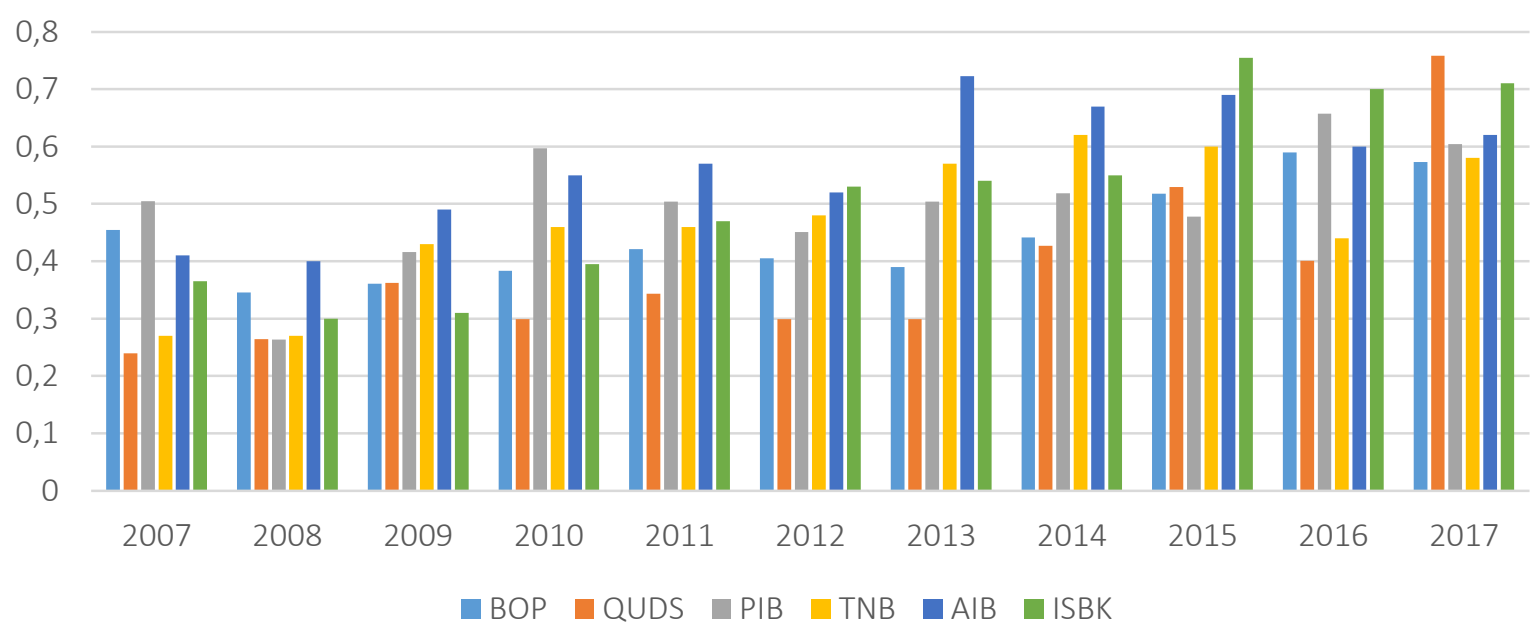

Figure 5. Liquid asset ratios of listed banks (2007-2017) 
Table 10. Composite rating based on the CAMEL rating system

\begin{tabular}{|c|c|c|c|c|c|c|c|}
\hline Bank & C & A & M & $E$ & $\mathbf{L}$ & Average rating & Composite rank \\
\hline BOP & 1 & 2 & 1 & 1 & 2 & 1.4 & 1 \\
\hline QUDS & 1 & 5 & 3 & 2 & 3 & 2.8 & 4 \\
\hline PIBC & 1 & 4 & 2 & 2 & 2 & 2.2 & 3 \\
\hline TNB & 1 & 4 & 5 & 4 & 2 & 3.2 & 5 \\
\hline $\mathrm{AlB}$ & 1 & 2 & 3 & 2 & 1 & 1.8 & 2 \\
\hline ISBK & 1 & 3 & 1 & 1 & 1 & 1.4 & 1 \\
\hline
\end{tabular}

acceptable and received a ranking of 3. However, QUDS and TNB both showed acceptable results with some weaknesses and were rated 4 and 5, respectively.

\subsection{Comparative analysis}

Table 11 exhibits the results of a sample t-test, used to determine whether there are differences in financial soundness among local Palestinian banks evaluated by the acronyms of CAMEL. In general, the results show that the $\mathrm{p}$-value for all CAMEL components among Palestinian banks is less than $5 \%$, thus, the second alternative hypothesis is accepted. This indicates that there are significant differences in means among listed banks assessed by the CAMEL rating system, which leads to the conclusion that the application of the CAMEL framework differs from one bank to another.

\section{DISCUSSION}

The results showed that all selected banks have committed to the Basel Accords capital requirements. The average capital adequacy ratio (22\%) for the period of study exceeds the standard of $10 \%$. This finding indicates that Palestinian banks have the ability to absorb any potential losses and to protect investors from external threats. Thus, this conclusion is in line with that of Chen (2003),

Table 11. The results of one sample t-test who argued that higher levels of capital adequacy prevent banks from bankruptcy and liquidation.

Regarding asset quality, the results indicate that non-performing loans have fluctuated over the period of study. The average of NPLs has been reduced by banks to just $4 \%$. This means that Palestinian banks have a well-defined credit policy and are able to efficiently manage credit risk. This finding supports the prior work by Rahman and Islam (2018).

Operational efficiency was deemed fairly efficient with an average OE/OI of $79 \%$. This indicates that bank operating revenue is higher than their operating expenses. Palestinian banks have the ability to manage their operational losses, which contradicts Desta (2016).

Profitability was fair with an average ROA of less than $1 \%$ during the study period. Due to political factors, Palestinian commercial banks have adopted a conservative credit policy regarding the issuance of loans in order to avoid credit risk. This finding is consistent with the previous study of Kullab and Yan (2018).

The results also showed that the selected banks have high liquidity. The average liquid asset ratio was $48 \%$ of bank assets during the study period. This indicates that the banks were able to meet

\begin{tabular}{|c|c|c|c|c|c|c|c|c|c|c|}
\hline \multirow{2}{*}{ Bank } & \multicolumn{2}{|c|}{ C } & \multicolumn{2}{|c|}{ A } & \multicolumn{2}{|c|}{ M } & \multicolumn{2}{|c|}{ E } & \multicolumn{2}{|c|}{$\mathbf{L}$} \\
\hline & t-value & Sig. & t-value & Sig. & t-value & Sig. & t-value & Sig. & t-value & Sig. \\
\hline $\mathrm{BOP}$ & 18.135 & 0.000 & 8.263 & 0.000 & 14.914 & 0.000 & 12.324 & 0.000 & 17.780 & 0.000 \\
\hline QUDS & 12.106 & 0.000 & 2.938 & 0.015 & 17.406 & 0.000 & 2.044 & 0.068 & 8.536 & 0.000 \\
\hline PIBC & 28.702 & 0.000 & 5.530 & 0.000 & 19.371 & 0.000 & 8.937 & 0.000 & 15.704 & 0.000 \\
\hline TNB & 6.541 & 0.000 & 5.027 & 0.001 & 17.563 & 0.000 & 0.798 & 0.443 & 13.002 & 0.000 \\
\hline AlB & 18.324 & 0.000 & 6.459 & 0.000 & 16.863 & 0.000 & 5.809 & 0.000 & 17.557 & 0.000 \\
\hline ISBK & 8.908 & 0.000 & 4.582 & 0.001 & 11.984 & 0.000 & 3.950 & 0.003 & 10.539 & 0.000 \\
\hline
\end{tabular}


their short-term obligations, which contradicts Kullab and Yan (2018).

The results of one sample t-test indicate that all p-values of CAMEL components are less than the significance level of $5 \%$, which shows that there are significant differences amongst Palestinian banks in terms of performance, assessed by the CAMEL rating system.

\section{CONCLUSION}

Despite the unstable investment environment of the Palestinian economy, commercial banks have achieved fair financial soundness, and they are all subject to financial fluctuations due to political instability. Therefore, this paper aims to evaluate the financial performance of Palestinian banks listed on PEX, assessed by the CAMEL rating system over eleven years (2007-2017). Based on this rating system, the study ranked overall performance of the listed banks on a scale from 1 to 5 . Additionally, a sample t-test was used to examine whether there are differences in terms of performance among selected banks.

The paper found that Palestinian commercial banks are committed to the Basel Accords and international standards in having a capital adequacy of $10 \%$. The average CAR for all banks amounted to $22.2 \%$ over the past eleven years. Thus, all listed banks received a ranking of 1 . This indicates that Palestinian banks follow conservative policies towards their invested capital. As for non-performing loans, this study found that Palestinian banks are tentative in minimizing their percentage of loans that are written off. Therefore, the average of NPLs for all banks is $4 \%$, with a rating of 3. Moreover, management efficiency of Palestinian banks varies from one bank to another. However, this paper found that Palestinian banks are fairly efficient and the average ratio of $\mathrm{OE} / \mathrm{OI}$ is $79 \%$, with a rating of 3 . This implies that Palestinian commercial banks perform well in terms of management efficiency. Furthermore, liquidity levels of listed Palestinian commercial banks are well managed, and they have sufficient funds to repay in the event of occasional withdrawals and short-term liabilities. The average of excess cash is $48 \%$ of assets and ranks 2 .

Palestinian bank performance is assessed using the composite CAMEL rating system. The paper found that the Bank of Palestine and the Palestinian Islamic Bank topped their counterparts with a rating of 1, while the Arab Islamic Bank received a rating of 2. The Palestinian Investment Bank received a rating of 3, while Quds Bank and The National Bank received a rating of 4 and 5, respectively. Finally, the paper reveals that there are significant differences among Palestinian banks' performances assessed by the CAMEL rating system. This paper suggests that Palestinian listed banks should focus on long-term investments rather than short-term ones and closely monitor their risk management practices. This study also recommends that policymakers draw attention to the problem of credit risk management and collaterals when financing investment projects.

\section{REFERENCES}

1. Abusharbeh, M. T. (2017). The impact of Banking Sector Development on Economic Growth: Empirical analysis from Palestinian economy. Journal of Emerging Issues in Economics, Finance and Banking, 6(2), 2306-2316. Retrieved from http://globalbizresearch.org/economics/ images/files/26543_D756_JEIEFB_Mohammed\%20T.\%20 Abusharbeh.pdf
2. Ally, Z. (2013). Comparative Analysis of financial performance of commercial banks in Tanzania. Research Journal of Finance and Accounting, 4(19), 133-143. Retrieved from http://citeseerx. ist.psu.edu/viewdoc/download?d $\mathrm{oi}=10.1 .1 .1013 .689 \& \mathrm{rep}=\mathrm{rep} 1 \& \mathrm{t}$ ype $=$ pdf

3. Aspal, P. K., \& Dhawan, S. (2016). Camels rating Model for evaluating financial performance of banking sector: A Theoretical Per- spective. International Journal of System Modeling and Simulation, 1(3), 10-15. Retrieved from http:// researchplusjournals.com/index. php/IJSMS/article/view/223

4. Aspal, P. K., \& Misra, S. K. (2013). A camel model analysis of State Bank Group. World Journal of Social Sciences, 3(4), 36-55. Retrieved from https://eclass.aueb. gr/modules/document/file.php/ LOXR307/paper_CAMEL_model. pdf 
5. Barr, R., Killgo, K., Siems, T., \& Zimmel, S. S. (2002). Evaluating the Productive Efficiency and Performance of U.S. Commercial Banks. Engineering Management, 28(8), 3-25. Retrieved from https://doi. org/10.1108/03074350210767988

6. Chen, J. (2003). Capital Adequacy of Chinese Banks: Evaluation and Enhancement. Journal of Banking Regulations, 4(4), 320-327. https://doi.org/10.1057/palgrave. jbr.2340149

7. Chytis, E., Chatzi, I. G., \& Diakomihalis, M. N. (2015). Performance of the Greek banking sector pre and throughout the financial crisis. Journal of Risk and Control, 2(1), 45-69. Retrieved from https://ideas.repec.org/a/rmk/rmkjrc/v2y2015ilp45-69.html

8. Correia, C., Dillon, J., Flynn, O., Uliana, E., \& Wormald, M. (2013). Financial Management (8th ed.). Cape Town: Juta Legal and Academic Publishers.

9. Dang, U. (2011). A CAMEL Rating System in Banking Supervision: A Case Study (Master Thesis). International Business Program, Arcada University of Applied Sciences. Retrieved from https:// www.theseus.fi/bitstream/ handle/10024/38344/Dang_Uyen. pdf ? sequence $=1$ \&isAllowed $=y$

10. Dash, M., \& Das, A. (2010). CAMELS Analysis of Indian Banking Industry. Social Sciences Research. http://dx.doi.org/10.2139/ ssrn. 1666900

11. Desta, T. (2016). Financial Performance of the best African Banks: comparative analysis through CAMEL rating. Journal of Accounting and Management, 6(1), 1-20. Retrieved from https:// pdfs.semanticscholar.org/fbba/ a7ele3dd26da01cff5ea000d$200 \mathrm{bb} 4 \mathrm{c} 7 \mathrm{db} 8 \mathrm{c}$.pdf?_ga $=2.2340$ 66582.989960769.1584088917446559412.1584088917

12. Doorasamy, M. (2016). Using DuPont analysis to assess the financial performance of the top 3 JSE listed companies in the food industry. Investment Management and Financial Innovations, 13(2), 29-44. http://dx.doi.org/10.21511/ imfi.13(2).2016.04
13. Ebhodghe, J. (1991). Bank Deposit insurance Scheme in Nigeria. NDIC Quarterly, 1(1), 17-25.

14. Kyriazopoulos, G., Papaioannou, P., \& Chrissochoidou, N. (2013). $\mathrm{Du}$ Pont analysis of the world systematic Banks. Presented paper at International Conference ABSRC, Rome, Italy. October 2-4. Retrieved from https://www.researchgate. net/publication/297575091_DU_ PONT_ANALYSIS_OF_THE_ WORLD_SYSTEMIC_BANKS Kyriazopoulos_Georgios_Applicant_Professor_kyriazopoulosgyahoocom_Papaioannou_Pantelis_Student_in_the_department_of_Accounting_and_Financial_Management_in_

15. Federal Deposit Insurance Corporation. (1997). Uniform Financial Institutions Rating System (UFIRS). Statements of Policy, the United States: Federal Deposit Insurance Corporation (FDIC).

16. Gupta, R. C. (2014). Analysis of Indian public sector of banks using CAMEL approach. Journal of Business and Management, 16(1), 94-102. Retrieved from http://iosrjournals.org/iosr-jbm/ papers/Vol16-issue1/Version-4/ L0161494102.pdf

17. Hawaldar, I. T., Lokesha, Kumar, K. A., Pinto, P., \& Sison, S. M. (2017). Performance analysis of commercial banks in the United Kingdom of Bahrain (2001-2015). International Journal of Economics and Financial Issues, 7(3), 729-737. Retrieved from https://www.researchgate.net/ publication/318112629_Performance_Analysis_of_Commercial_ Banks_in_the_Kingdom_of_Bahrain_2001-2015

18. Hirtle, B. J., \& Lopez, J. A. (1999). Supervisory Information and the Frequency of Bank Examination. FRBNY Economic Policy Review, 5(1), 1-19. Retrieved from https:// papers.ssrn.com/sol3/papers. cfm?abstract_id=1004357

19. Ishaq, A. B., Karim, A., Zaheer, A., \& Ahmed, S. (2016). Evaluating performance of commercial banks in Pakistan: An application of camel model. Journal of Business \& Financial Affairs, 5(1), 1-30. https://doi.org/10.4172/21670234.1000169
20. Kullab, Y., \& Yan, C. (2018). Soundness of Palestinian banks-10 years based analysis. Journal of Business and Management, 20(8), 16-29. Retrieved from https:// www.researchgate.net/publication/326912093_Soundness_of_ Palestinian_Banks-10_Years_ Based_Analysis

21. Kumar, V., \& Sayani, H. (2015). Application of CAMEL model on the GCC Islamic banks 2008-2014. Journal of Islamic Banking and Finance, 3(2), 1-14. https://doi. org/10.15640/jibf.v3n2al

22. Kumari, I. G. S. (2017). A study of the financial performance on foreign commercial banks in Sri Lanka: An application of CAMEL Rating System. Economics, Commerce and Trade Management: An International Journal, 1(1), 59-70. Retrieved from https://airccse. com/ectij/papers/1117ectij05.pdf

23. Liu, J., \& Pariyaprasert, W. (2014). Determinants of Bank Performance: The Application of the CAMEL Model to Banks Listed in China's Stock Exchanges from 2008 to 2011. AU-GSB e-JOURNAL, 7(2), 80-95. Retrieved from https://pdfs.semanticscholar.org/ d607/3e0b35cab4160d0ab52439e5 93ed90df05a0.pdf?_ga =2.16087221.247239732.15844325332100778558.1584432533

24. Mekonnen, Y., Kedir, H., \& Shibru, M. (2015). Soundness of Ethiopian Banks. International Journal of Finance and Banking Studies, 4(2), 29-37. Retrieved from https:// www.researchgate.net/publication/282642311_Soundness_of_ Ethiopian_Banks

25. Najjar, N. J. (2013). Can financial ratios reliably measure the performance of banks in Bahrain? International Journal of Economics and Finance, 5(3), 152-163. https://doi. org/10.5539/ijef.v5n3p152

26. Palestinian Monetary Authority. (2018). Financial Stability Report (FSR) 2017. Palestine: Rammallah. Retrieved from http://www.pma. ps/en-us/publications/annualreports.aspx

27. Rahman, Z., \& Islam, S. (2018). Use of CAMEL Rating Framework: A Comparative Perfor- 
mance Evaluation of Selected Bangladeshi Private Commercial Banks. International Journal of Economics and Finance, 10(1), 120-128. https://doi.org/10.5539/ ijef.v10n1p120

28. Raiyani, J. (2010). Effect of mergers on efficiency and productivity of Indian banks: A CAMELS analysis. Asian Journal of Management Research, 772-794. Retrieved from http://citeseerx. ist.psu.edu/viewdoc/download?d oi $=10.1 \cdot 1.298 .3492 \&$ rep $=$ rep $1 \& \mathrm{t}$ ype $=$ pdf

29. Roman, A., \& Şargu, A. C. (2013). Analyzing the financial soundness of the commercial banks in Romania: an approach based on the CAMELS framework. Procedia Economics and Finance, 6, 703-712. https://doi.org/10.1016/ S2212-5671(13)00192-5

30. Rostami, M. (2015). Determination of CAMELS model on Bank's Performance. International Journal of Multidisplinary Research and Development, 2(10), 652-664. Retrieved from https:// www.researchgate.net/publication/283457724_Determination_ of_Camels_model_on_bank's_ performance

31. Sarker, A. (2006). CAMELS rating system in the context of Islamic banking: A proposed 'S' for Shariah framework. Journal of Islamic Economics and Finance, 1(1), 78-84.
Retrieved from https://ibtra.com/ pdf/journal/v2_n2_article4.pdf

32. Soni, R. (2012). Applicability of CAMELS Rating for Supervisory Regulation of the Indian Banking System. Vishwakarma Business Review, 2(2), 14-20. Retrieved from http://www.i-scholar.in/index.php/ VBRVIM/article/view/64314

33. Sundararajan, V., Enoch, Ch., San José, A., Hilbers, P., Krueger, R., Moretti, M., \& Slack, G. (2002). Financial Soundness Indicators: Analytical Aspects and Country Practices (Occasional Paper 212). Washington DC: International Monetary Fund. Retrieved from https://rbidocs.rbi.org.in/rdocs/ content/PDFs/75443.pdf 